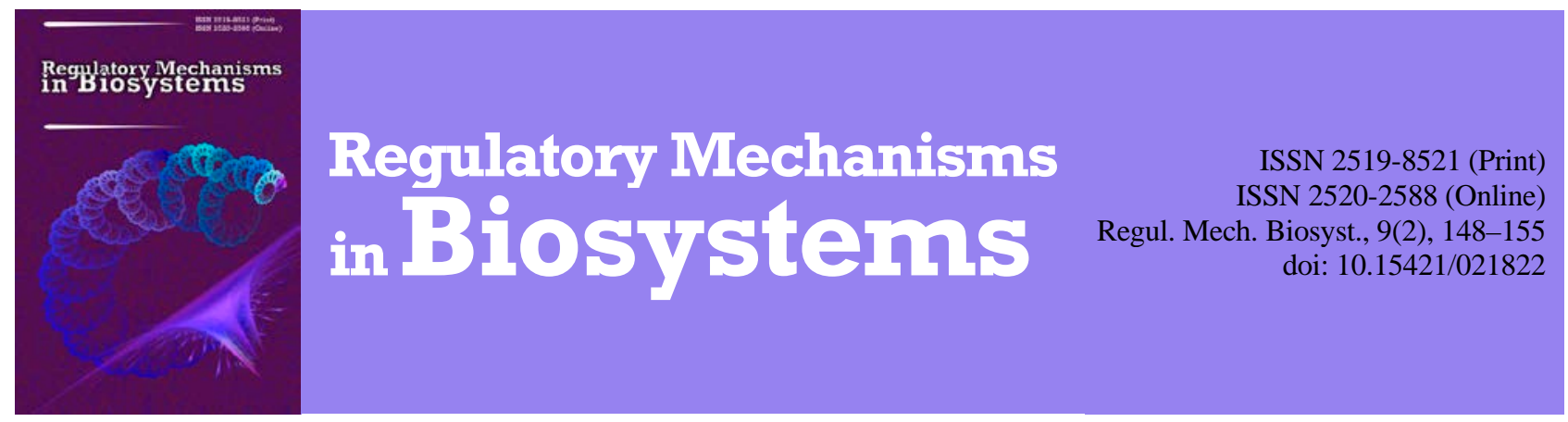

\title{
Activity of nitrogen fixation and antioxidant enzymes in symbiotic systems Glycine max - Bradyrhizobium japonicum for complex treatment with lectin and fungicides
}

\author{
S. Y. Kots, T. P. Mamenko, A. V. Pavlyshche \\ Institute of Plant Physiology and Genetics, National Academy of Sciences of Ukraine, Kyiv, Ukraine
}

Article info

Received 02.02.2018

Received in revised form 27.03.2018

Accepted 29.03.2018

Institute of Plant Physiology and Genetics, National Academy of Sciences of Ukraine,

Vasylkivska st., 31/17, Kyiv, 03022, Ukraine.

Tel.: +38-044-257-51-50.

E-mail:t_mamenko@ukt.net
Kots, S. Y., Mamenko, T. P., \& Pavlyshche, A. V. (2018). Activity of nitrogen fixation and antioxidant enzymes in symbiotic systems Glycine max - Bradyrhizobium japonicum for complex treatment with lectin and fungicides. Regulatory Mechanisms in Biosystems, 9(2), 148-155. doi:10.15421/021822

The dynamics of the nitrogen fixation activity of the root nodules, the growth of the vegetative mass of plants and the change in the activity of antioxidant enzymes (superoxide dismutase, ascorbate and guaiacol peroxidase) in different soybean organs for treatment of seeds by rhizobia incubated with lectin, in combination with fungicides have been studied. The objects of the study were symbiotic systems formed with the participation of soybean (Glycine max (L.) Merr.) Almaz and Bradyrhizobium japonicum (standard strain 634b) incubated with lectin. As disinfectants of soybean seeds, the following preparations with fungicidal activity were used - Maxim XL 035 PS, Fever, Standak Top according to one rate of active substance consumption of each preparation specified by the manufacturer. One part of the seeds treated with fungicides was inoculated with pure culture of suspension of rhizobia for one hour (titre of suspension concentration was $10^{8}$ cells/ml). Another part of the seeds treated with fungicides was inoculated with rhizobia suspension, which was previously incubated with a solution of commercial lectin soybean at a concentration of $100 \mu \mathrm{g} / \mathrm{ml}$. The research was conducted in strictly controlled conditions of a model vegetative experiment using microbiological, physiological, biochemical methods, gas chromatography, spectrophotometry. It was found that processing of soybean seeds with fungicides (Fever and Maxim XL) together with rhizobium inoculation contributed to the preservation of the nitrogen fixation activity of the root nodules and the growth of vegetative mass of plants. Under these conditions, the intensification of the activity of superoxide dismutase and ascorbate peroxidase was observed, as well as inhibition of the activity of guaiacol peroxidase in soybean root nodules in the phase of three true leaves and increased activity of all investigated enzymes in the phase of mass flowering. It has been established that the use of complex treatment of seeds by soybean rhizobia incubated with lectin and fungicides leads to an increase in the activity of superoxide dismutase and guaiacol peroxidase in root nodules in the phase of three true leaves and the growth of the activity of ascorbate peroxidase in the phase of mass flowering. At the same time, the inhibition of the growth of vegetative mass of plants and their symbiotic properties occurred, as evidenced by the decrease in the nitrogen fixation activity of the root nodules for the joint treatment of seeds with fungicides and lectin. A specific reaction of investigated enzymes in the roots and leaves of soybean was shown, which was more pronounced in the phase of three true leaves, indicating the development of a typical antioxidant reaction to a complex treatment, as a kind of stress that is leveled to the phase of mass flowering. The degree of reaction of antioxidant enzymes in the studied symbiotic systems Glycine max - Bradyrhizobium japonicum depends on the nature of the active substance fungicides and the manifestation of their joint effect in a complex with rhizobia incubated with lectin.

Keywords: soybean; rhizobia; superoxide dismutase; guaiacol peroxidase; ascorbate peroxidase; symbiosis

\section{Активність азотфіксації та антиоксидантних ферментів у симбіотичних системах Glycine max - Bradyrhizobium japonicum за комплексної обробки лектином і фунгіцидами}

\author{
С. Я. Коць, Т. П. Маменко, А. В. Павлище \\ Інститут фізіологї рослин і генетики НАН Украӥни, Київ, Украӥна
}

Досліджено динаміку азотфіксувальної активності кореневих бульбочок, наростання вегетативної маси рослин та зміни активності антиоксидантних ферментів (супероксиддисмутази, аскорбат- і гваяколпероксидази) у різних органах сої за обробки насіння ризобіями, інкубованими з лектином, у комплексі з фунгіцидами. Об'єкти дослідження - симбіотичні системи, утворені за участю сої (Glycine тах 
(L.) Merr.) сорту Алмаз і Bradyrhizobium japonicum (штам-стандарт 634б), інкубованих із лектином. Як протруювачі насіння сої використано препарати $з$ фунгіцидною активністю Максим XL 035 PS, Февер, Стандак Топ із розрахунку однієї норми витрат діючої речовини кожного препарату, вказаної виробником. Одну частину обробленого фунгіцидами насіння інокулювали чистою культурою суспензії ризобій протягом однієї години (титр концентрації суспензії становив $10^{8}$ кл./мл). Іншу частину обробленого фунгіцидами насіння інокулювали суспензією ризобій, яка попередньо була інкубована з розчином комерційного лектину сої у концентрації 100 мкг/мл. Дослідження проводили у суворо контрольованих умовах модельного вегетаційного досліду з використанням мікробіологічних, фізіологічних, біохімічних методів, газової хроматографії, спектрофотометрії. Обробка насіння сої фунгіцидами (Февер і Максим XL) спільно з інокуляцією ризобіями сприяла збереженню азотфіксувальної активності кореневих бульбочок і наростанню вегетативної маси рослин. За таких умов обробки відбувалась інтенсифікація активності супероксиддисмутази та аскорбатпероксидази, а також пригнічення активності гваяколпероксидази в кореневих бульбочках сої у фазу трьох справжніх листків та підвищення активності всіх досліджуваних ферментів у фазу масового цвітіння. Комплексна обробка насіння сої ризобіями, інкубованими з лектином, і фунгіцидами, підвищувала активність супероксиддисмутази та гваяколпероксидази в кореневих бульбочках у фазу трьох справжніх листків та сприяла зростанню активності аскорбатпероксидази у фазу масового цвітіння. При цьому відбувалось пригнічення наростання вегетативної маси рослин та їх симбіотичних властивостей, що проявлялось у зниженні азотфіксувальної активності кореневих бульбочок за спільної обробки насіння фунгіцидами та лектином. Показано специфічну реакцію досліджуваних ферментів у коренях і листках сої, яка була більш вираженою у фазу трьох справжніх листків. Це свідчить про розвиток типової антиоксидантної реакції на комплексну обробку як своєрідний стрес, який нівелювався до фази масового цвітіння. Ступінь реакції досліджуваних антиоксидантних ферментів у симбіотичних системах Glycine max Bradyrhizobium japonicum залежав від характеру діючої речовини фунгіцидів та прояву їх впливу в комплексі з ризобіями, інкубованими з лектином.

Ключові слова: соя; ризобії; супероксиддисмутаза; гваяколпероксидаза; аскорбатпероксидаза; симбіоз

\section{Ветуп}

Соя - одна 3 найбільш високорентабельних передових культур у сільськогосподарському виробництві України та світу в цілому, цікавість до вирощування якої з кожним роком інтенсивно зростає, що відмічається зростанням посівних площ і урожайності насіння (Sergienko, 2012; Kobak et al., 2016). Одна 3 причин недобору врожаю сої - ураження ії фітопатогенними мікроорганізмами - втрати врожаю зерна від хвороб досягають $30-40 \%$. Тому важлива складова технології вирощування сої - захист ії від фітопатогенних організмів (Sergienko, 2012).

Все більша увага дослідників спрямовна до вирішення питання порушення рівноваги в системі «рослина - патоген - довкілля» (Kobak et al., 2016). У період вегетації рослин варто проводити інтегровану систему захисту посівів, залежно від їх фітосанітарного стану. Це гармонійно поєднані усі сучасні методи захисту: організаційно-господарські, агротехнічні, імунологічні, біологічні та хімічні засоби (Мarco, 2013). Разом із тим, одна з основних проблем захисту рослин - не стільки використання хімічних засобів захисту рослин, скільки пошук шляхів зниження рівня їх шкодочинності для навколишнього середовища (Mohammadi et al., 2012; Petrichenko \& Kots, 2014).

Один із важливих факторів захисту рослин сої від хвороб і шкідників - обробка насіння протруйниками в комплексі із застосуванням інокулянтів на основі мікросимбіонтів B. јаропісит, які, у свою чергу, сприяють півищенню стресостійкості та продуктивності рослин (Nikolaevsky et al., 2017). Рослини сої з активним симбіотичним апаратом стійкіші до ураження широким спектром хвороб, а чітке поєднання всіх заходів, направлених на оптимізацію симбіозу, сприяє формуванню потужного симбіотичного апарату, полыпшенню фітосанітарного стану посівів, підвищенню родючості грунту та отриманню високих урожаїв сої $з$ найкращими якісними показниками (Nikolaevsky et al., 2017).

Розкриття особливостей формування захисних реакцій у симбіозі бобових рослин із штамами бульбочкових бактерій важливе для пошуку ефективних симбіотичних систем, здатних реалізувати свій адаптивний потенціал за дії стрес-факторів, а розширення та поглиблення досліджень у цьому напрямку передбачає удосконалення існуючих і створення нових фізіолого-біохімічних засобів регуляції їх адаптаційної здатності у стресових умовах (Моhammadi et al., 2012).

Інвазія ризобій у клітини кореневих волосків бобових подібна до процесу патогенезу - це своєрідний стрес для рослини, який може викликати інтенсифікацію окисних процесів та підвищення вмісту активних форм кисню (АФК) (Iturbe-Ormaetxe et al., 2001; Zhiznevskaya, 2001; Matamoros et al., 2003). У свою чергу, АФК можуть виступати як сигнальні молекули, що беруть участь в активації захисних систем за дії стресу, зокрема, індукувати синтез ферментів антиоксидантів (Mittler, 2002). Основний ініціатор вільнорадикального окиснення ліпідів мембран - супероксид, що ге- нерується у багатьох спонтанних і ензиматичних реакціях окиснення, причому продуктами його вторинного перетворення можуть бути синглетний кисень, гідроксильний радикал, пероксид водню, органічні пероксиди та їх радикали (Shao et al., 2008; Sharma et al., 2012). Тому ключовий ензим захисту живих організмів від окисної деструкції - супероксиддисмутаза (СОД), яка каталізує утворення пероксиду водню та кисню з аніон-радикалів супероксиду (Raychauhuri \& Deng, 2000; Alser et al., 2002). Для утилізації пероксиду водню $\left(\mathrm{H}_{2} \mathrm{O}_{2}\right)$ включається комплекс ензимів: каталаза, родина пероксидаз - аскорбатпероксидаза (АПО) та гваяколпероксидаза (ГПО). У літературі пероксидазну реакцію розглядають як відповідь на проникнення ризобій у рослинну клітину (Zhiznevskaya, 2001). Водночас пероксидази можуть нести достатньо інформації про фізіологічний стан рослини та слугувати критерієм стійкості до дії стресових чинників (Matamoros et al., 2003).

Існує три ізоформи СОД (CuZn-COД, Fe-СОД i Mn-COД) у рослинних клітинах, які відрізняються наявністю металу в активному центрі ензиму. Всі вони виявлені в рослинних фракціях кореневих бульбочок бобових рослин (Moran et al., 2003; Rubio et al., 2004). Різна локалізація ізоензимів СОД у тканинах кореневих бульбочок зумовлює їх специфічні функції. Зокрема, CuZn-COД переважає в апексі бульбочок, особливо в інфекційних нитках, у цитозолі, розташованому поряд із клітинними оболонками, та апопласті. Функція CuZn-COД може бути пов'язана з ростом клітинних стінок у меристемах, інфекційних нитках і апопласті, а також із відповіддю рослин на бактеріальну інфекцію. Мn-СОД присутній в інфікованих клітинах кореневих бульбочок і бере участь у процесах, пов'язаних із захистом і функціонуванням симбіозу у зрілих бульбочках. Fе-СОД локалізований винатково у стромі хлоропластів, його функції менш за все вивчено у бобових рослин. Бактероїди містять Mn-COД у цитозолі та CuZn-COД у периплазматичному просторі. Ці ензими кодуються відповідними бактеріальними sodA i sodC генами (Moran et al., 2003; Rubio et al., 2004).

АПО - ключовий фермент аскорбат-глутатіонового циклу утилізації $\mathrm{H}_{2} \mathrm{O}_{2}$, основа функціонування кореневих бульбочок (Dalton et al., 1993). В інфікованих клітинах фермент захищає леггемоглобін та інші білки від $\mathrm{H}_{2} \mathrm{O}_{2}$, тоді як у паренхімі клітин бульбочок він бере участь у створенні дифузійного бар'єру для кисню, контролюючи таким чином його надходження в інфіковану зону (Schmitz et al., 1997; Dalton et al., 1998).

У рослинних клітинах існує так званий III клас пероксидаз, які використовують як субстрати похідні фенолів. Ще їх називають неспецифічними чи класичними. Вони містяться у вакуолях і цитоплазмі, залучені до великої кількості процесів у рослинних клітинах, зокрема, лігніфікації, обпробковіння, катаболізму ауксину, захисту проти дії патогенів і окисного стресу (Erofeeva, 2015; Parsiavash et al., 2015). До них відносять і ГПО.

Важливу роль у формуванні захисної відповіді рослин за дії стресових чинників біотичної та абіотичної природи відіграють поліфункціональні білки - фітолектини (Babosha, 2008; Hivrale \& 
Ingale, 2013). Лектини здатні оборотно та неспецифічно зв'язувати вуглеводні залишки різної хімічної природи, завдяки чому взаємодіють із поверхневими вуглеводами бактеріальної клітини під час утворення бобово-ризобіального симбіозу (Hoff et al., 2009; Кугуchenko, 2014). Разом із цим, саме лектин-вуглеводна взаємодія забезпечує зв'язування бактерій і викликає несумісну взаємодію партнерів, індукуючи захисні механізми рослин на ураження патогеном (Chrispeels \& Raikhel, 1991; Lehotzky et al., 2010).

Фізіологічна дія лектинів не обмежується лише властивостями лектинів зв'язувати вуглеводні залишки. Їх розглядать як сигнальні молекули, здатні індукувати складний ланцюг внутрішніх перетворень у клітині та їі відповідь (Owens et al., 2001; Kyrychenko, 2014). Припускають, що характерна особливість структури рослинних лектинів - це наявність центрів гідрофобного зв'язування, що вказує на наявність у них самостійних сайтів, які відповідають за гідрофобну взаємодію 3 молекулами невуглеводної природи, внаслідок чого вони можуть активно включатися в систему гормональної регуляції процесів росту та розвитку рослин (Moreira et al., 1991; Hoff et al., 2009). Зокрема, маючи два центри зв’язування, лектин одним із них вибірково взаємодіє з кислими ізоформами пероксидази, а другим - із хітином. У відповідь на інфікування патогенами в рослинах активуються кислі ізоформи пероксидази (аніонні), які в комплексі з лектином виконують захисну функцію (Hoff et al., 2009; Kyrychenko, 2014).

Численними дослідженнями показано, що за використання екзогенної обробки лектинами (передпосівна обробка насіння чи обприскування рослин після вегетації) змінюються ростові процеси та метаболізм рослин (Owens et al., 2001), азотфіксувальних мікроорганізмів (Kyrychenko, 2014), фітопатогенних грибів (Hoff et al., 2009), індукується формування захисних реакцій рослин на дію стресових чинників (Babosha, 2008). Як вважає Kyrychenko (2014), це розкриває перспективність практичного використання таких білків як природних регуляторів росту.

У зв'язку з вищевказаним мета нашої роботи - дослідити зміни активності АПО та ГПО в різних органах рослин сої за обробки насіння ризобіями, інкубованими 3 лектином спільно 3 фунгіцидами. Це дозволить з'ясувати додаткові аспекти ролі цього білка у формуванні захисних реакцій симбіотичних систем за участю сполук із фунгіцидною дією.

\section{Матеріал і методи досліджень}

Об'єкти дослідження - симбіотичні системи, утворені за участю сої (Glycine max (L.) Merr.) сорту Алмаз і B. japonicum (штамстандарт 634б), інкубовані з лектином. Як протруювачі насіння сої використали препарати з фунгіцидною активністю Февер (Bayer CropScience AG, Німеччина), Максим XL (Syngenta, Швейцарія), Стандак Топ (BASF, Німеччина). Культуру повільнорослих бульбочкових бактерій вирощували на твердому манітно-дріжджовому середовищі протягом 7 діб за $26-28^{\circ} \mathrm{C}$.

Перед посівом насіння стерилізували $70 \%$ розчином етанолу та промивали проточною водою. Потім насіння сої обробляли розчинами фунгіцидів - Максим XL 035 PS (флудіоксоніл, 25 г/л, металаксил, 10 г/л), Февер (протіоконазол, 300 г/л), Стандак Топ (фіпроніл, 250 г/л, тіофанат-метил, 225 г/л, піраклостробін, 25 г/л) із розрахунку однієї норми витрат діючої речовини кожного препарату, вказаної виробником. Одну частину обробленого фунгіцидами насіння інокулювали чистою культурою суспензії ризобій протягом однієї години (титр концентрації суспензії становив $10^{8}$ кл./мл). Іншу частину обробленого фунгіцидами насіння інокулювали суспензією ризобій, яка попередньо була інкубована 3 розчином комерційного лектину сої («Лектинотест», м. Львів) у концентрації 100 мкг/мл. Тривалість інкубації з лектином становила 20 годин за температури $28^{\circ} \mathrm{C}$.

Рослини вирощували у 4-кілограмових посудинах у піщаній культурі із внесенням поживної суміші Гельрігеля з 0,25 норми азоту за природного освітлення та оптимального водозабезпечення (70\% від повної вологоємності). Контролем слугував варіант 3 інокуляцією насіння ризобіями без використання лектину та без обробки фунгіцидами. Азотфіксувальну активність (АФА) визначали ацетиленовим методом (Hardy, 1968) на газовому хроматографi «Agilent GC system 6850» (США) з полуменево-іонізаційним детектором. Розділення газів проводили на колонці (Supelco Porapak N) за температури термостата $55^{\circ} \mathrm{C}$ і детектора $-150{ }^{\circ} \mathrm{C}$. Газом-носієм був гелій (20 мл/хв). Об'єм аналізованої проби газової суміші становив $1 \mathrm{~cm}^{3}$. Як стандарт використовували чистий етилен (Sigma-Aldrich, № 536164, США). Наростання вегетативної маси рослин контролювали ваговим методом. Вимірювання показників АФА, надземної маси та маси кореня проводили у 6-разовій повторності.

Для отримання ензимного екстракту наважку рослинного матеріалу $(0,2$ г) розтирали у ступці з 4 мл охолодженого 50 мМ фосфатного буферу (pH 7,5), який містив 2 мМ етилендіамінтетраоцтову кислоту (ЕДТА), 1 мМ фенілметилсульфонілфторид, 5 мМ $\beta$-меркаптоетанол і $1 \%$ (в/о) полівінілпіролідон. Гомогенат центрифугували за 10000 об./хв протягом 20 хв за $4{ }^{\circ} \mathrm{C}$. Супернатант використовували для визначення активності ензимів за допомогою спектрофотометра «Smart Spec Plus» (CША).

Активність АПО (КФ 1.11.1.11) визначали за зменшенням оптичної густини за довжини хвилі 290 нм протягом хвилини у результаті окиснення аскорбату $\left(\varepsilon=2,8 \mathrm{MM}^{-1} \mathrm{~cm}^{-1}\right)$ (Nakano \& Asada, 1981). Реакційна суміш містила $50 \mathrm{мM}$ калій-фосфатний буфер (pH 7,0), 0,1 мМ ЕДТА, 0,2 мМ аскорбат, 0,1 мМ $\mathrm{H}_{2} \mathrm{O}_{2}$. Реакцію ініціювали додаванням 150 мкл супернатанта. Активність ГПО (КФ 1.11.1.7) - за збільшенням оптичної густини за 470 нм протягом хвилини у результаті окиснення гваяколу $\left(\varepsilon=26,6 \mathrm{MM}^{-1} \mathrm{~cm}^{-1}\right)$ (Egley et al., 1983). Реакційна суміш містила 50 мМ калій-фосфатний буфер (pH 7,0), 0,1 мМ ЕДТА, 0,5\% гваякол, 10 мМ Н $\mathrm{O}_{2}$. Реакцію ініціювали додаванням 50 мкл супернатанта. Активність СОД (КФ 1.15.1.1) визначали за здатністю ензиму інгібувати фотохімічне відновлення нітросинього тетразолію (Raychauhuri \& Deng, 2000). Реакційна суміш містила 50 мМ фосфатний буфер (pH 7,8), 13 мМ метіонін, 2 мкМ рибофлавін, 63 мкМ р-нітросиній тетразолій, 0,1 мМ ЕДТА і 100 мкл ферментного екстракту. Реакція тривала протягом 15 хвилин за інтенсивності світла 70 мкмоль квантів/( $\left.\mathrm{m}^{2} \cdot \mathrm{c}\right)$ освітлення флуоресцентними лампами потужністю 15 Вт. Оптичну густину вимірювали за 560 нм. Вміст загального розчинного протеїну у ферментному екстракті визначали за Bradford (1976). Активність ферментів визначали у 4-кратній повторності. Одержані дані оброблені статистично, значення $\mathrm{P}<0,05$ розглядали як критерій значущості різниці. У таблицях $1-4 \mathrm{i}$ на рисунках 1-4 наведено середні арифметичні значення та їх стандартні похибки (SE).

\section{Результати}

Інокуляція насіння сої ризобіями, інкубованими 3 лектином, сприяла підвищенню ефективності симбіотичного апарату. Це проявлялось у стимуляції АФА кореневих бульбочок, яка зростала за дії лектину на 20\% порівняно з контролем у фазу трьох справжніх листків та масового цвітіння (рис. 1). Разом із тим, у фазу бутонізації не зафіксовано істотної різниці АФА між варіантами з використанням лектину та без його участі.

Обробка насіння сої фунгіцидами по-різному впливала на процеси функціонування симбіотичного апарата в рослин на фоні бактеризації ризобіями. Серед усіх досліджуваних препаратів із фунгіцидною активністю у варіанті з обробкою насіння фунгіцидом Стандак Топ зафіксоване найбільше пригнічення АФА кореневих бульбочок, особливо у фазу трьох справжніх листків (на $60 \%$ порівняно з контрольними рослинами, рис. 1).

Передпосівна обробка насіння фунгіцидами Февер і Максим XL проявляла меншу токсичну дію на АФА кореневих бульбочок. У фазу трьох справжніх листків у варіантах з обробкою цими препаратами спостерігали незначне підвищення АФА, показники якої у наступні фази онтогенезу дещо знижувались порівняно 3 контрольним варіантом (за дії Максиму XL), або були в межах похибки досліду (за дії Феверу). Обробка насіння сої досліджуваними фунгіцидами на фоні бактерізації B. japопісит, інкубованих із лек- 
тином, викликала пригнічення ефективності роботи симбіотичного апарату, про що свідчить суттєве зниження процесів азотфіксації кореневих бульбочок порівняно з рослинами контрольного варіанта (рис. 1). Зокрема, у варіанті з обробкою насіння Стандак Топом і ризобіями, інкубованими з лектином, виявлене найбільше зниження АФА (до 70\%) кореневих бульбочок упродовж онтогенезу.
Водночас, оброблення насіння сої фунгіцидами Февер і Максим XL спільно з інокуляцією ризобіями, інкубованими з лектином, чинила менш виражений токсичний вплив на симбіотичний апарат. У фази трьох справжніх листків і бутонізації АФА кореневих бульбочок знижувалась порівняно з контролем (на $40 \%$ - Февер та $47 \%$ Максим, тоді як у фазу цвітіння - на 25\% і 27\%, відповідно).

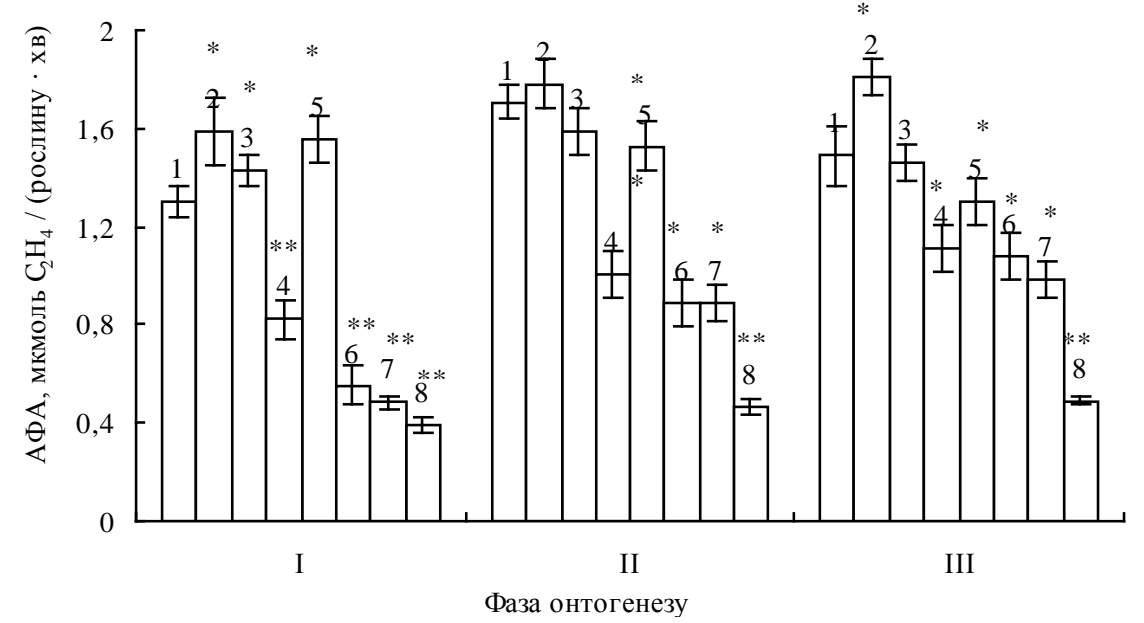

Рис. 1. Вплив обробки насіння сої В. јаропісит 634б, інкубованими з лектином, спільно із фунгіцидами на азотфіксувальну активність

(АФА) кореневих бульбочок у фазу трьох справжніх листків (I), бутонізації (II) та масового цвітіння (III) ( $\mathrm{n}=6, \mathrm{x} \pm \mathrm{SE}$ ):

тут і на рис. 2-4: 1 - ризобії (контроль), 2 - (ризобії + лектин), 3 - ризобії + Максим XL, 4 - (ризобії + лектин) $)_{\mathrm{i}}+$ Максим XL,

5 - ризобії + Февер, 6 - (ризобії + лектин $)_{\mathrm{i}}+$ Февер, 7 - ризобії + Стандак Топ, 8 - (ризобії + лектин) $)_{\mathrm{i}}+$ Стандак Топ; i - інкубація компонентів протягом 20 годин за $28^{\circ} \mathrm{C}$; дані порівняно $з$ контролем вірогідні за * $-\mathrm{P}<0,05$, ** $-\mathrm{P}<0,01$, ***-P $<0,001$

У рослин, насіння яких піддавали обробці фунгіцидами та інокулювали суспензією ризобій, інкубованих із лектином, відбулось пригнічення ростових процесів у фази трьох справжніх листків і бутонізації (табл. 1). У фазу цвітіння такий ефект впливу комплексної обробки вже був не так сильно виражений. Найбільшу токсичну дію на наростання надземної маси та маси кореневої системи чинив подібний комплекс із протруйником Стандак Топ. У фазу трьох справжніх листків ці показники були нижчими до $40 \%$ від контролю, а у фазу бутонізації - до $30 \%$. Поєднання подібного комплексу з фунгіцидом Максим викликало зниження кореневої маси рослин сої на 29\% порівняно з контрольними рослинами у фазу трьох справжніх листків. У фазу бутонізації рослини цього варіанта досліду характеризувались нижчою масою як надземних органів (на 12\%), так і кореневої системи (на 16\% порівняно 3 контролем). Лише комбінація обробки насіння Февером спільно з ризобіями, інкубованими з лектином, не впливала на досліджуваний показник. У варіантах досліду без використання лектину не зафіксовано подібного інгібувального ефекту від досліджуваних фунгіцидів на ростові параметри рослин (табл. 1). Інокуляція сої ризобіями, інкубованими з лектином, індукувала різку інтенсифікацію активності СОД у кореневих бульбочках у фазу трьох справжніх листків, майже удвічі порівняно $з$ контролем (табл. 2). У фазу масового цвітіння активність ферменту не суттєво зростала, однак була на $23 \%$ вищою за рівень контрольних рослин.

\section{Таблиця 1}

Вплив обробки насіння сої В. јаропісит 634б, інкубованими з лектином, спільно з фунгіцидами, на наростання вегетативної маси рослин (г/рослину, $\mathrm{n}=6, \mathrm{x} \pm \mathrm{SE})$

\begin{tabular}{|c|c|c|c|c|c|c|}
\hline \multirow{3}{*}{ Варіант } & \multicolumn{6}{|c|}{ Фаза онтогенезу } \\
\hline & \multicolumn{2}{|c|}{ трьох справжніх листків } & \multicolumn{2}{|c|}{ бутонізації } & \multicolumn{2}{|c|}{ масового цвітіння } \\
\hline & надземна маса & маса кореня & надземна маса & маса кореня & надземна маса & маса кореня \\
\hline ризобії (контроль) & $3,52 \pm 0,21$ & $2,71 \pm 0,18$ & $3,63 \pm 0,25$ & $2,71 \pm 0,21$ & $4,80 \pm 0,28$ & $2,50 \pm 0,18$ \\
\hline (ризобії + лектин) & $3,87 \pm 0,30 *$ & $2,58 \pm 0,20^{*}$ & $3,91 \pm 0,22 *$ & $3,55 \pm 0,14^{* *}$ & $5,70 \pm 0,36^{*}$ & $4,07 \pm 0,33 * * *$ \\
\hline ризобії + Февер & $3,52 \pm 0,14$ & $2,46 \pm 0,22 *$ & $3,60 \pm 0,28$ & $3,48 \pm 0,27 * *$ & $5,54 \pm 0,22 *$ & $3,53 \pm 0,29 * *$ \\
\hline ризобії+ Максим XL & $3,49 \pm 0,33$ & $2,60 \pm 0,19 *$ & $4,48 \pm 0,33 * *$ & $3,30 \pm 0,27 * *$ & $4,70 \pm 0,16$ & $4,66 \pm 0,29 * * *$ \\
\hline ризобії + Стандак Топ & $3,11 \pm 0,17^{*}$ & $2,11 \pm 0,17^{* *}$ & $3,30 \pm 0,14^{*}$ & $3,06 \pm 0,28 * *$ & $4,93 \pm 0,13$ & $3,19 \pm 0,29 * *$ \\
\hline (ризобії + лектин) $)_{\mathrm{i}}+$ Февер & $3,41 \pm 0,27$ & $2,26 \pm 0,18^{* *}$ & $3,43 \pm 0,19 *$ & $2,40 \pm 0,23^{*}$ & $4,83 \pm 0,23$ & $3,10 \pm 0,21^{* *}$ \\
\hline (ризобії + лектин) $)_{\mathrm{i}}+$ Максим XL & $3,18 \pm 0,17^{*}$ & $1,94 \pm 0,08 * *$ & $3,20 \pm 0,12^{*}$ & $2,28 \pm 0,18^{*}$ & $5,15 \pm 0,29 *$ & $2,68 \pm 0,25$ \\
\hline (ризобії + лектин) + Стандак Топ & $2,25 \pm 0,22 * * *$ & $1,71 \pm 0,09 * * *$ & $2,46 \pm 0,19 * * *$ & $2,25 \pm 0,19 *$ & $4,24 \pm 0,32 *$ & $2,24 \pm 0,11^{*}$ \\
\hline
\end{tabular}

Примітка: тут і в табл. $2-4$ i - інкубація компонентів протягом 20 годин за $28{ }^{\circ} \mathrm{C}$; дані порівняно 3 контролем вірогідні за * $-\mathrm{P}<0,05$, ** $-\mathrm{P}<0,01$, *** $-\mathrm{P}<0,001$.

Обробка насіння сої фунгіцидами спільно з ризобіями спричиняла підвищення активності СОД у кореневих бульбочках у фазу трьох справжніх листків. За таких умов обробки активність ферменту не суттєво зростала у фазу масового цвітіння. Подібну тенденцію зміни активності СОД у кореневих бульбочках зафіксовано за комплексної обробки насіння фунгіцидами спільно 3 ризобіями, інкубованими з лектином. Динаміка активності СОД за комплексної обробки насіння характеризувалась суттєвим зростанням у фазу трьох справжніх листків і незначним у фазу масового цвітіння, незалежно від характеру діючої речовини фунгіциду та їх спільного впливу з ризобіями, інкубованими з лектином.
Інокуляція сої ризобіями, інкубованими з лектином, спричиняла підвищення активності АПО в кореневих бульбочках, порівняно $з$ контролем у фази трьох справжніх листків і масового цвітіння (табл. 3). При цьому ми не зафіксували суттєвих змін активності ГПО (у межах похибки досліду) (табл. 4).

Обробка насіння сої препаратами з фунгіцидною дією на фоні бактеризації ризобіями індукувала підвищення активності АПО та різке пригнічення активності ГПО у кореневих бульбочках порівняно $з$ контрольними рослинами у фазу трьох справжніх листків (табл. 3,4$)$. У фазу масового цвітіння, відбувалась інтенсифікація активності АПО та наближення рівня активності ГПО до контролю. 
Таблиця 2

Вплив обробки насіння сої В. japonicum 634б, інкубованого з лектином, спільно із фунгіцидами, на активність супероксиддисмутази (СОД) у кореневих бульбочках (од. а./мг білка, $\mathrm{n}=4, \mathrm{x} \pm \mathrm{SE}$ )

\begin{tabular}{lcc}
\hline \multirow{2}{*}{ Варіант } & \multicolumn{2}{c}{ Фаза онтогенезу } \\
\cline { 2 - 3 } & три справжні листки & масового цвітіння \\
\hline ризобії (контроль) & $24,3 \pm 1,2$ & $20,4 \pm 1,2$ \\
(ризобії + лектин) & $46,5 \pm 3,1^{* * *}$ & $25,1 \pm 1,5^{*}$ \\
ризобії + Февер & $43,2 \pm 2,6^{* * *}$ & $23,8 \pm 1,4^{*}$ \\
ризобії + Максим XL & $40,4 \pm 3,6^{* * *}$ & $23,3 \pm 1,4^{*}$ \\
ризобії + Стандак Топ & $35,5 \pm 1,5^{* *}$ & $26,9 \pm 1,6^{*}$ \\
(ризобії + лектин) + Февер & $33,3 \pm 1,6^{* *}$ & $22,9 \pm 1,4^{*}$ \\
(ризобії + лектин) $)_{i}+$ Максим XL & $38,8 \pm 3,8^{* *}$ & $24,5 \pm 1,5^{*}$ \\
(ризобії + лектин) + Стандак Топ & $33,9 \pm 2,5^{* *}$ & $23,1 \pm 1,4^{*}$ \\
\hline
\end{tabular}

\section{Таблиця 3}

Вплив обробки насіння сої В. japonicum 634б, інкубованого з лектином, спільно із фунгіцидами, на активність аскорбатпероксидази (АПО)

у кореневих бульбочках (мкмоль аскорбату/мг білка $\cdot$ хв, $\mathrm{n}=4, \mathrm{x} \pm \mathrm{SE}$ )

\begin{tabular}{|c|c|c|}
\hline \multirow{2}{*}{ Варіант } & \multicolumn{2}{|c|}{ Фаза онтогенезу } \\
\hline & три справжні листки & масового цвітіння \\
\hline ризобії (контроль) & $0,038 \pm 0,009$ & $0,096 \pm 0,018$ \\
\hline (ризобії + лектин $)_{i}$ & $0,091 \pm 0,020^{* * *}$ & $0,155 \pm 0,018^{* *}$ \\
\hline ризобії + Февер & $0,114 \pm 0,006^{* * *}$ & $0,191 \pm 0,016^{* * *}$ \\
\hline ризобії + Максим XL & $0,115 \pm 0,014^{* * *}$ & $0,140 \pm 0,022^{* *}$ \\
\hline ризобії + Стандак Топ & $0,217 \pm 0,020^{* * *}$ & $0,356 \pm 0,040^{* * *}$ \\
\hline (ризобії + лектин $)_{\mathrm{i}}+$ Февер & $0,039 \pm 0,006$ & $0,261 \pm 0,030 * * *$ \\
\hline (ризобії + лектин) + Максим XL & $0,089 \pm 0,012^{* * *}$ & $0,194 \pm 0,016^{* * *}$ \\
\hline (ризобіï + лектин) + Стандак Топ & $0,108 \pm 0,011^{* * *}$ & $0,260 \pm 0,030 * * *$ \\
\hline
\end{tabular}

\section{Таблиця 4}

Вплив обробки насіння сої В. japonicum 634б, інкубованого з лектином, спільно з фунгіцидами, на активність гваяколпероксидази (ГПО) у кореневих бульбочках (мкмоль гваяколу/мг білка $\cdot$ хв, $\mathrm{n}=4, \mathrm{x} \pm \mathrm{SE}$ )

\begin{tabular}{|c|c|c|}
\hline \multirow{2}{*}{ Варіант } & \multicolumn{2}{|c|}{ Фаза онтогенезу } \\
\hline & три справжні листки & масового цвітіння \\
\hline ризобії (контроль) & $0,145 \pm 0,011$ & $0,283 \pm 0,027$ \\
\hline (ризобії + лектин) & $0,162 \pm 0,010^{*}$ & $0,204 \pm 0,014^{*}$ \\
\hline ризобії + Февер & $0,078 \pm 0,018^{* *}$ & $0,225 \pm 0,007 *$ \\
\hline ризобії + Максим XL & $0,046 \pm 0,008^{* * *}$ & $0,173 \pm 0,013^{* *}$ \\
\hline ризобії + Стандак Топ & $0,041 \pm 0,008 * * *$ & $0,266 \pm 0,030 *$ \\
\hline (ризобії + лектин) $)_{\mathrm{i}}+$ Февер & $0,151 \pm 0,010^{*}$ & $0,176 \pm 0,016^{* *}$ \\
\hline$(\text { ризобії + лектин) })_{\mathrm{i}}+$ Максим XL & $0,268 \pm 0,011^{* * *}$ & $0,173 \pm 0,014^{* *}$ \\
\hline (ризобії + лектин) + Стандак Топ & $0,072 \pm 0,013^{* *}$ & $0,177 \pm 0,020 * *$ \\
\hline
\end{tabular}

Обробка насіння сої фунгіцидами Максим XL i Стандак Топ спільно з ризобіями, інкубованими з лектином, спричинила підвищення активності АПО в кореневих бульбочках у фазу трьох справжніх листків (табл. 3). У варіанті з подібною обробкою за використання фунгіциду Февер активність ферменту в кореневих бульбочках сої перебувала на рівні контрольних рослин. У фазу масового цвітіння його активність зростала в усіх варіантах $з$ обробкою насіння досліджуваними фунгіцидами та інокуляцією B. јаропісит, інкубованими з лектином.

Обробка насіння сої ризобіями, інкубованими з лектином, у комплексі з фунгіцидом Максим XL спричиняла підвищення активності ГПО в кореневих бульбочках у фазу трьох справжніх листків (табл. 4). За таких умов вирощування рослин та використання обробки насіння фунгіцидом Февер активність ферменту була на рівні контрольних рослин, тоді як за дії Стандак Топу знижувалась. У фазу масового цвітіння в усіх варіантах з обробкою насіння досліджуваними фунгіцидами спільно з ризобіями, інкубованими із лектином, активність ГПО у кореневих бульбочках знижувалась.

За інокуляції насіння сої ризобіями, інкубованими з лектином, активність СОД у коренях зростала у фазу трьох справжніх листків і досягала рівня конрольних рослин у фазу масового цвітіння (рис. 2). Обробка насіння сої фунгіцидами спільно з інокуляцією
B. јаропісит викликала підвищення активності ферменту в коренях порівняно з контролем у фазу трьох справжніх листків за дії Максиму (на 97\%) та Феверу (на 20\%), однак до зниження його активності за дії Стандак Топу на 23\%. У фазу масового цвітіння за таких умов обробки насіння активність ферменту в коренях сої знижувалась, особливо різко за дії Стандак Топу (на 42\%), Феверу (на 35\%), та незначно за дії Максиму (на 15\%) (рис. 2).

A
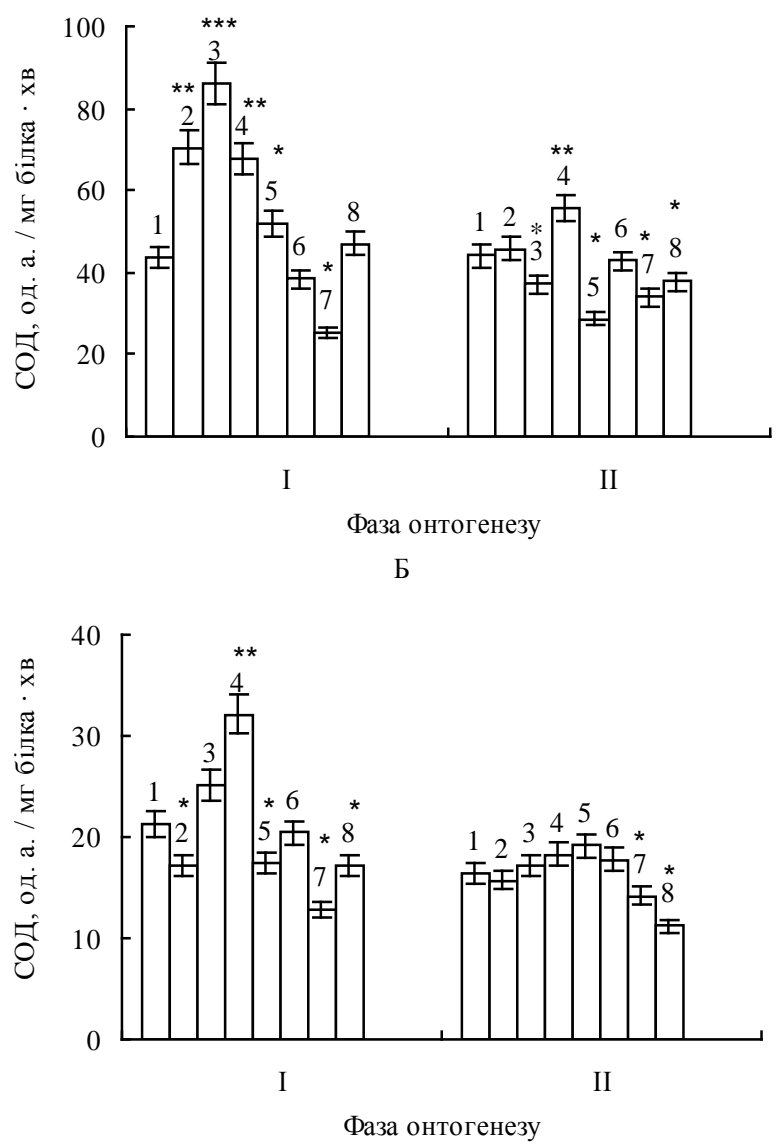

Рис. 2. Вплив обробки насіння сої В. jаропісит 634б, інкубованими з лектином, спільно із фунгіцидами, на активність супероксиддисмутази (СОД) у коренях $(A)$ і листках (Б) у фазу трьох справжніх листків (I) і масового цвітіння (II): $\mathrm{n}=4, \mathrm{x} \pm \mathrm{SE}$

Використання лектину як компонента інокуляційної суспензії спільно з обробкою насіння сої фунгіцидами індукувало підвищення активності СОД у коренях рослин у фазу трьох справжніх листків за дії Максиму (на 55\%) та не викликала суттєвих змін активності ферменту порівняно з контролем за дії Феверу та Стандак Топу. У фазу масового цвітіння тенденція активності СОД залишалась майже на такому ж рівні, як у фазу трьох справжніх листків, порівняно з конрольними рослинами.

Інокуляція насіння сої ризобіями, інкубованими $з$ лектином, викликала незначне зниження активності СОД у листках у фазу трьох справжніх листків та наближення рівня активності ферменту до контрольного у фазу масового цвітіння (рис. 2).

Використання обробки насіння сої фунгіцидами спільно з інокуляцією ризобіями спричиняло незначне підвищення активності ферменту в листках за дії Максиму (на 18\%), зниження його активності за дії Феверу (на 18\%) та, особливо, за дії Стандак Топу (на 39\%), порівняно з контролем у фазу трьох справжніх листків. Водночас у фазу масового цвітіння активність СОД у листках не суттєво відрізнялась від конролю за обробки Максимом і Февером і знижувалась за дії Стандак Топу.

Комплексна обробка насіння сої фунгіцидам і ризобіями, інкубованими з лектином, спричиняла підвищення активності СОД у листках у варіанті з Максимом (до 50\%), зниження - за викорис- 
тання Стандак Топу (до 32\%) і незначних змін порівняно з контролем у варіанті з Февером у фазу трьох справжніх листків. У фазу масового цвітіння подібний комплекс обробки за використання ризобій, інкубованих із лектином, спричинив зниження активності СОД у листках за дії Стандак Топу (до 20\%) і відсутність помітних змін активності ферменту за дії Максиму та Феверу.

Обробка насіння сої ризобіями, інкубованими з лектином, не викликала суттєвих змін активності АПО в коренях порівняно 3 контрольними рослинами (рис. 3). Водночас активність ферменту в листках за дії лектину зростала у фазу трьох справжніх листків і була на рівні контролю у фазу масового цвітіння.

У симбіотичних системах, утворених за участю сої, інокульованої B. japonicum, та за обробки насіння фунгіцидами, спостерігали підвищення активності ферменту в коренях за використання Максиму XL i зниження його активності за дії Феверу та Стандак Топу у фазу трьох справжніх листків (рис. 3). Реакція АПО в листках на обробку протилежна до зміни іiі активності в коренях: зростала за використання Феверу та Стандак Топу та знижувалась у варіанті з Максимом XL. У фазу масового цвітіння рівень активності ферменту в коренях дещо зростав або був у межах похибки досліду, тоді як його активність у листках знижувалась у всіх досліджуваних симбіотичних системах. Виняток - варіант із обробкою фунгіцидом Февер: активність ферменту знижувалась у коренях і листках порівняно з контрольними рослинами.

A
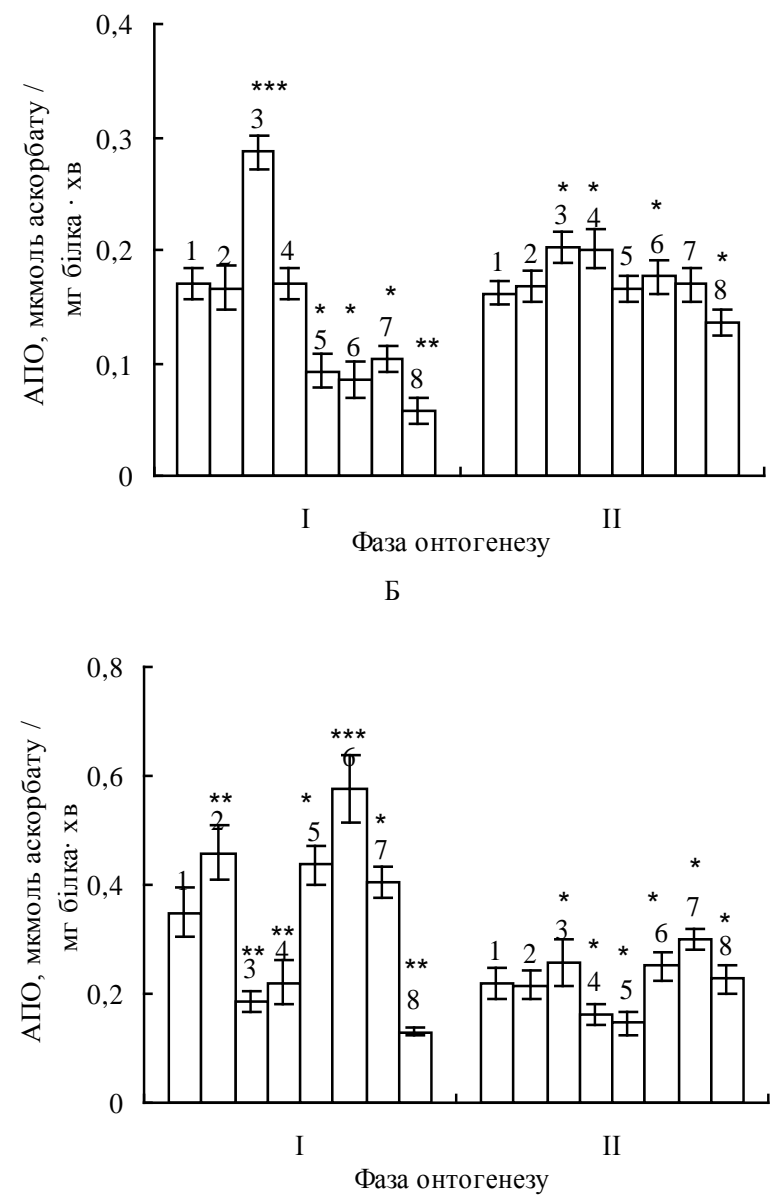

Рис. 3. Вплив обробки насіння сої В. japonicum 634б, інкубованими з лектином, спільно з фунгіцидами, на активність АПО у коренях $(A)$ і листках (Б) у фазу трьох справжніх листків $(I)$ та масового цвітіння (II): $\mathrm{n}=4, \mathrm{x} \pm \mathrm{SE}$

Виявлено подібну до обробки насіння ризобіями з фунгіцидами тенденцію зміни активності АПО в коренях і листках за комплексної обробки сої за участю лектинів (рис. 3). Іншу тенденцію спостерігали лише у фазу трьох справжніх листків у варіантах із подібним комплексом обробки насіння та використання Максиму XL i Феверу: активність ферменту в листках досягала рівня контрольних рослин.

За інокуляції насіння сої ризобіями, інкубованими з лектином, не відбувалось суттєвих змін активності ГПО в коренях, порівняно $з$ контрольними рослинами (рис. 4). При цьому активність ферменту в листках підвищувалася у фазу трьох листків та знижувалася у фазу масового цвітіння. Комплексна обробка насіння сої ризобіями та фунгіцидами Стадак Топ і Максим XL індукувала різку інтенсифікацію активності ГПО в коренях у фазу трьох справжніх листків (рис. 4). За дії фунгіциду Февер активність ферменту в коренях залишалась на рівні контрольних рослин.

A
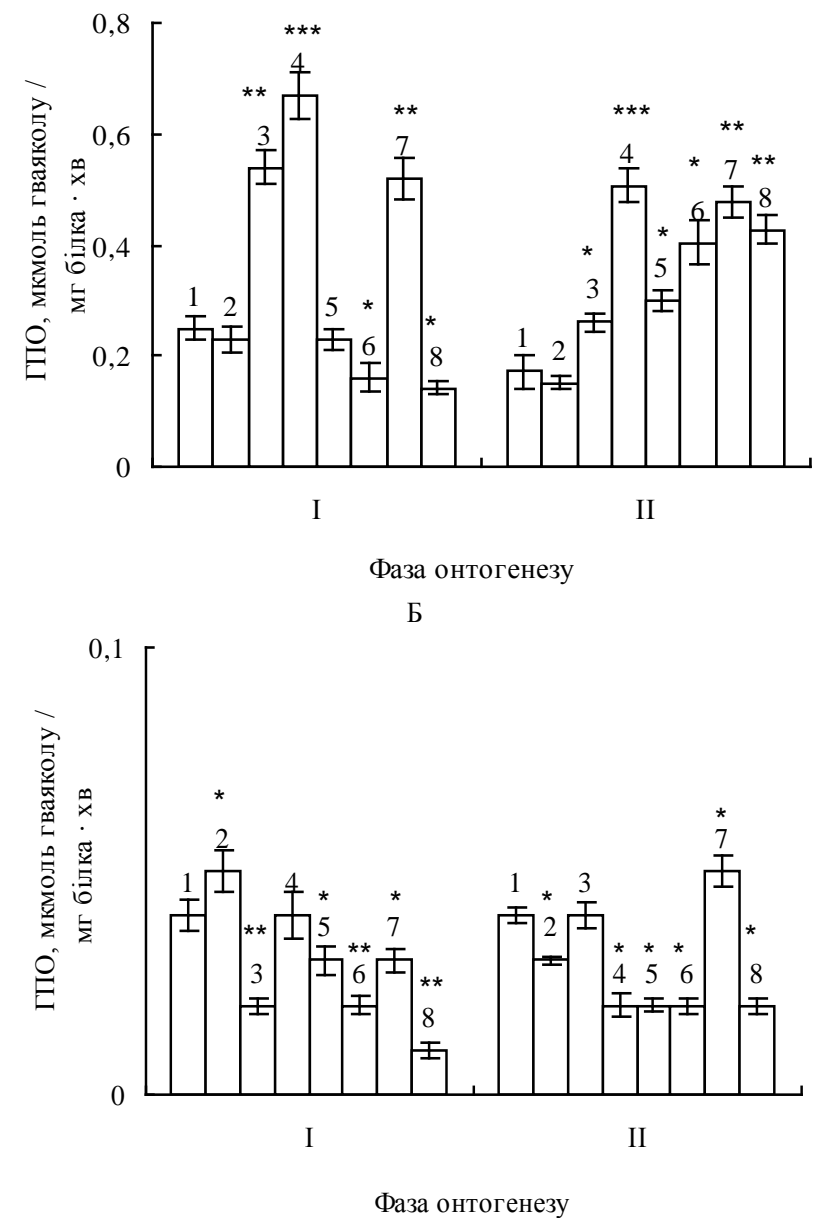

Рис. 4. Вплив обробки насіння сої В. japonicum 634б, інкубованими з лектином, спільно із фунгіцидами, на активність ГПО в коренях $(A)$ і листках $(Б)$ у фазу трьох справжніх листків $(I)$ та масового цвітіння (II): $\mathrm{n}=4, \mathrm{x} \pm \mathrm{SE}$

У фазу масового цвітіння рівень його активності в коренях зростав у всіх досліджуваних симбіотичних системах за участі ризобій і фунгіцидів, особливо за дії Стандак Топу. За комплексної обробки насіння ризобіями та фунгіцидами активність ГПО в листках істотно знижувалась у фазу трьох справжніх листків. У фазу масового цвітіння його активність наближалася до контрольного за дії Максиму XL, залишалася на низькому рівні за дії Феверу та зростала за дії Стандак Топу.

Обробка насіння ризобіями, інкубованими з лектином, спільно $з$ фунгіцидом Максим XL спричиняла стрімке зростання активності ГПО в коренях у фазу трьох справжніх листків, тоді як подібна обробка за участю фунгіцидів Февер і Стандак Топ індукувала зниження активності ферменту в коренях порівняно з контролем. У фазу масового цвітіння активність ферменту в коренях перебувала на досить високому рівні в цих симбіотичних системах. Інокуляція сої ризобіями, інкубованими 3 лектином, спільно 3 
обробкою насіння фунгіцидами індукувала зниження активності ГПО в листках порівняно з контролем як у фазу трьох справжніх листків, так і у фазу масового цвітіння. Особливо у варіанті з комплексною обробкою насіння зі Стандак Топом, у фазу трьох справжніх листків.

\section{Обговорення}

Складові механізмів дії лектинів на рослини - їх залучення до сигнальної системи регуляції росту та розвитку за безпосередньої взаємодії з фітогормонами. Рістстимулювальна дія лектинів пов’язана зі змінами балансу фітогормонів у бік накопичення індоліл оцтової кислоти (IОК) та цитокінінів у рослині (Kyrychenko, 2014). Підвищення активності пероксидази як поліфункціонального ферменту розглядають серед інших іiі функцій у клітині ще й як відповідь на збільшення вмісту ендогенного ауксину, а за рівнем активності пероксидази у рослинах можна судити про вміст у них ауксинів, зокрема IOK (Fedorova et al., 2000). Зафіксовані нами зміни активності антиоксидантних ферментів у створених симбіотичних системах за обробки насіння ризобіями, інкубованими з лектином, спільно $з$ фунгіцидами, можуть бути пов'язані саме 3 порушенням регуляторної функції ендогенних лектинів.

Як зазначено вище, характерна особливість структури рослинних лектинів - наявність центрів гідрофобного зв’язування. Це вказує на наявність у них самостійних сайтів, які відповідають за гідрофобну взаємодію з молекулами невуглеводної природи, зокрема фітогормонами, внаслідок чого вони можуть активно включатися в систему гормональної регуляції процесів росту та розвитку рослин (Babosha, 2008; Kyrychenko, 2014). Можна припустити, що діючі речовини досліджуваних фунгіцидів індукували блокування гідрофобних сайтів зв’язування в молекулі білка, чим створювалась своєрідна конкуренція за сайти зв'язування з іншими хімічними сполуками, що спричинило зміни процесів формування та функціонування соєво-ризобіального симбіозу.

Дослідженнями останніх років показано, що негативний вплив препаратів із фунгіцидною активністю на ефективність бобово-ризобіального симбіозу пов'язаний із порушенням регуляторної системи сигналів між макро- та мікросимбіонтами, блокуванням активності генів нодуляції та зменшенням рівня ризобіального Nodфактора (Bikrol et al., 2005; Fox et al., 2007; Araujo et al., 2017). Пестициди можуть впливати через інгібування флавоноїдного Nodрецептора, індукуючи пригнічення синтезу та секреції флавоноїдних речовин, що виробляються рослиною, тим самим порушуючи бобово-ризобіальну взаємодію (Bikrol et al., 2005; Fox et al., 2007; Araujo et al., 2017). Кожна 3 досліджуваних хімічних речовин конкурентно обмежувала активацію генного Nod-фактора залежно від ііі концентрації та інгібувальної дії.

Отримані нами дані свідчать, що використання інокуляційної суспензії ризобій, інкубованих із лектином, у комплексі з фунгіцидами пригнічувало ріст сої (надземної маси та маси кореня), що супроводжувалось зниженням ефективності роботи симбіотичного апарату. Крім того зафіксовано різний ступінь впливу досліджуваних препаратів із фунгіцидною дією на ефективність функціонування соєво-ризобільного симбіозу. На нашу думку, такий вплив препаратів залежав від характеру діючих речовин, що входять до ï складу, та здатності утворених симбіотичних систем реалізувати свої симбіотичні властивості за певних умов вирощування.

Аналіз отриманих результатів показав, що обробка насіння сої ризобіями, інкубованими $з$ лектином, у комплексі з фунгіцидами підвищує активність СОД і ГПО в кореневих бульбочках у фазу трьох справжніх листків і стимулює зростання активності АПО у фазу масового цвітіння. Це свідчить про активацію захисних реакцій рослин на рівні роботи ферментів 3 антиоксидантною активністю, ступінь якої відрізняється залежно від характеру впливу діючої речовини досліджуваних фунгіцидів. Специфічною реакцією ферментів (СОД, АПО та ГПО) на комплексну обробку відрізнявся варіант із використанням фунгіциду Стандак Топ. На нашу думку це пов'язано з хімічним складом зазначеного препарату, присутністю трьох діючих речовин (фіпронілу, тіофанат-метилу, піраклостробіну), які поєднують фунгіцидну та інсектицидну дію. Поєднання такого комплексу хімічних сполук негативно впливає на метаболічні процеси рослин сої в симбіозі з ризобіями. При цьому найсильніший негативний вплив на соєво-ризобіальний симбіоз, очевидно, спричинений саме наявністю у складі препарату діючої речовини тіофанат-метилу, який належить до класу бензимідазолів, що відрізняються низькою хімічною стабільністю та під час попаданя у грунт швидко (протягом декількох годин або навіть хвилин) гідролізуються до стійкішої сполуки - карбендазиму 3 періодом напіврозпаду $\left(\mathrm{T}_{0,5}\right)$ 3-6 місяців (Evtushenko et al., 2004). Як зазначають літературні джерела, тіофанат-метил потрапляє через коріння та переміщується в рослині в акропетальному напрямку ксилемою, точніше, його метаболіт карбендазим, який характеризується тератогенними, ембріотоксичними, гонадотоксичними та канцерогенними властивостями (www.demetra-agra.com.ua).

Вплив діючої речовини (протіоконазолу, клас триазоли), що входить до складу препарату Февер, полягає в інгібуванні диметилази - ферменту, який відповідає за біосинтез стеролів (будівельний матеріал клітин патогену) та спричиняє порушення цілісності клітинних стінок грибів, їх загибель (Kobak et al., 2016). Проникаючи в рослини, триазоли можуть порушувати синтез гіберелінів у рослині та діяти як регулятори росту, спричиняючи ретардантний ефект. Тривалість $\mathrm{T}_{0,5}$ цієї речовини залежить від $\mathrm{pH}$ навколишнього середовища: у лужному - понад рік, у кислому - до 120 діб, у водних фотолітичних умовах - до 48 годин (Evtushenko et al., 2004). У наших дослідженнях застосовано обробку насіння чистою культурою В. јаропісит 6346 (pH 7,2) спільно з водним розчином препарату Февер, із наступним вирощуванням рослин у піщаній культурі зі внесенням поживної суміші Гельрігеля, тобто були створені контрольовані умови з підтриманням нейтрального $\mathrm{pH}$ грунту, що могло бути причиною для нетривалого періоду дії препарату та його менш шкодочинного впливу на соєво-ризобіальний симбіоз порівняно з іншими досліджуваними фунгіцидами.

До складу препарату Максим XL входять дві діючі речовини (флудіоксоніл і металаксил), одна з яких, флудіоксоніл, - аналог природного антибіотика, що виділяється грунтовими бактеріями Pseudomonas pyrocinia, які пригнічують ріст патогенних грибів (www.demetra-agra.com.ua). Вплив речовин підкласу триазолінтіонів на ріст і розмноження патогену пов'язують із порушенням функції клітинних мембран. Однак, вбиваючи збудників хвороб, цей препарат безпечний, не пригнічує корисну мікрофлору грунту. Тривалість $\mathrm{T}_{0,5}$ в грунті - 10-25 діб (Evtushenko et al., 2004). Тому фунгіцидна дія Максиму не проявляла значного токсичного впливу на реалізацію симбіотичних властивостей сої.

Реакція антиоксидантних ферментів (СОД, АПО і ГПО) в коренях і листках сої як на спільну обробку ризобіями та фунгіцидами, так і на комплексну обробку за участю гомологічного лектину більш виражена у фазу трьох справжніх листків порівняно 3 фазою масового цвітіння. Очевидно, це повязано з реакцією ферментів на обробку як своєрідний стрес для рослини, який нівелюється до фази масового цвітіння. При цьому ступінь прояву активності досліджуваних ферментів відрізнявся між варіантами залежно від характеру впливу діючої речовини досліджуваних фунгіцидів, а також специфічності прояву їх спільного впливу з ризобіями, інкубованими з лектином. У фазу масового цвітіння у досліджуваних симбіотичних системах спостерігали зниження рівня активності ферментів (СОД, АПО і ГПО) в листках незалежно від хімічної природи фунгіцидних препаратів та прояву їх дії в комплексі з ризобіями, інкубованими з лектином. 3 одного боку, це може бути пов'язано з онтогенетичними перебудовами метаболізму рослин і переходом їх у генеративну фазу онтогенезу, з іншого - зі зниженням хімічної активності діючих речовин препаратів унаслідок їх повного чи часткового розпаду у грунті $\left(\mathrm{T}_{0,5}\right)$.

\section{Висновки}

Інтенсифікація активності СОД, АПО та пригнічення активності ГПО в кореневих бульбочках сої за дії фунгіцидів у фазу трьох справжніх листків та підвищення активності всіх досліджу- 
ваних ферментів у фазу масового цвітіння вказує на суттєвий розвиток стресзахисних реакцій у відповідь на обробку. При цьому використання комплексної обробки насіння сої фунгіцидами (Февер і Максим XL) та інокулянтом (штам В. japonicum 634б) сприяе збереженню АФА кореневих бульбочок і наростанню вегетативної маси рослин.

Оробка насіння сої ризобіями, інкубованими з лектином, спільно $з$ фунгіцидами викликає підвищення активності СОД і ГПО в кореневих бульбочках у фазу трьох справжніх листків і зростання активності АПО у фазу масового цвітіння, що свідчить про розвиток типової антиоксидантної реакції у відповідь на комплексну обробку. Водночас, використання гомологічного лектину сої в концентрації 100 мкг/мл як компонента інокуляційної суспензії для пом'якшення токсичної дії досліджуваних фунгіцидів на функціонування соєво-ризобіального симбіозу не виправдало очікуваних результатів у суворо контрольованих умовах модельного вегетаційного досліду та потребує подальших досліджень у грунтовій культурі.

Активність антиоксидантних ферментів (СОД, АПО і ГПО) в коренях і листках сої як на спільну обробку ризобіями та фунгіцидами, так і на комплексну обробку за участю гомологічного лектину була вираженішою у фазу трьох справжніх листків порівняно 3 фазою масового цвітіння, що пов’язано з реакцією ферментів на обробку як своєрідний стрес для рослини, який нівелюється до фази масового цвітіння.

\section{References}

Alscher, R. G., Erturk, N., \& Heath, L. S. (2002). Role of superoxide dismutases (SODs) in controlling oxidative stress in plants. Journal of Experimental Botany, 53(372), 1331-1341.

Araujo, R. S., Cruz, S. P., Souchie, E. L., Martin, T. N., Nakatani, A. S., Nogueira, M. A., \& Hungria, M. (2017). Preinoculation of soybean seeds treated with agrichemicals up to 30 days before sowing: Technological innovation for large-scale agriculture. International Journal of Microbiology, 1-11.

Babosha, A. V. (2008). Inducible lectins and plant resistance to pathogens and abiotic stress. Biochemistry, 73(7), 812-825 (in Russian).

Bikrol, A., Saxena, N., \& Singh, K. (2005). Response of Glycine max in relation to nitrogen fixation as influenced by fungicide seed treatment. African Journal of Biotechnology, 4(7), 667-671.

Bradford, M. A. (1976). Rapid and sensitive method for the quantitation of the microgram quantities of protein utilising: The principle of protein - dye binding. Analytical Biochemistry, 72, 248-254.

Chrispeels, M. J., \& Raikhel, N. V. (1991). Lectins, lectin genes and their role in plant defence. Plant Cell, 3, 1-9.

Dalton, D. A., Baird, L. M., Langeber, L., Taugher, C. Y., Anyan, W. R., Vance, C. P., \& Sarath, G. (1993). Subcellular localization of oxygen defense enzymes in soybean (Glycine max (L.) Merr.) root nodules. Plant Physiology, 102(1), 481-489.

Dalton, D., Joyner, S. L., Becana, M., Iturbe-Ormaetxe, I., \& Chatfield, J. M. (1998). Antioxidant defenses in the peripheral cell layers of legume root nodules. Plant Physiology, 116, 37-43.

Egley, G. H., Paul, R. N., Vaughn, K. C., \& Duke, S. O. (1983). Role of peroxidase in the development of water impermeable seed coats in Sida sprinosa L. Planta, 157(1), 224-232.

Erofeeva, E. A. (2015). Dependence of guaiacol peroxidase activity and lipid peroxidation rate in drooping birch (Betula pendula Roth) and tillet (Tilia cordata Mill.) leaf on motor traffic pollution intensity. Dose-Response: An International Journal, 1-6.

Evtushenko, M. D., Marutin, F. M., Turenko, V. P., Zherebko, V. M., \& Sekun, M. P. (2004). Phytopharmacologia. Vusha Osvyta, Kyiv (in Ukrainian).

Fedorova, E. E., Zhivnevskaya, G. Y., Kalibernaya, Z. V., Artemenko, E. N., Izmailov, S. F., \& Gus'kov, A. V. (2000). Metabolism of IOA with the establishment of symbiosis between Phaseolus vulgaris and Rhizobium phaseoli. Russian Journal of Plant Physiology, 47(2), 231-235 (in Russian).

Fox, J. E., Gulledge, J., Engelhaupt, E., Burow, M. E., \& McLachlan, J. A. (2007). Pecticides reduce symbiotic efficiency of nitrogen-fixing rhizobia and host plants. Proceeding of the National Academy of Sciences USA, 104(24), 10282-10287.
Hardy, R. W. F., Holsten, R. D., Jackson, E. K., \& Burns, R. C. (1968). The acetylene-ethylene assay for nitrogen fixation: Laboratory and field evalution. Plant Physiology, 43(8), 1185-1207.

Hivrale, A. U., \& Ingale, A. G. (2013). Plant as a plenteous reserve of lectin. Plant Signaling and Behavior, 8(12), 1-7.

Hoff, P. L. D., Brill, L. M., \& Hirsch, A. M. (2009). Plant lectins: The ties that bind in root symbiosis and plant defense. Molecular Genetics Genomics, 282(1), 1-15.

Iturbe-Ormaetxe, J., Matamoros, M. A., Rubio, M. C., Dalton, D. A., \& Becana, M. (2001). The antioxidant of legume nodule mitochondria. Molecular PlantMicrobe Interaction, 14(10), 1189-1196.

Kobak, S. Y., Kolisnik, S. I., \& Serevetnyk, O. V. (2016). The most common diseases of soybean and the effectiveness of BASF products for their control. Agrobusiness Today, 10(329), 46-47 (in Ukrainian).

Kyrychenko, E. V. (2014). Phytolectines and diazotrophs - polyfunctional components of complex biological compositions. Biotechnologia Acta, 7(1), 4053 (in Ukrainian).

Lehotzky, R. E., Partch, C. L., Mukherjee, S., Cash, H. L., Goldman, W. E., Gardner, K. H., \& Hooper, L. V. (2010). Molecular basis for peptidoglycan recognition by a bactericidal lectin. Proceeding of the National Academy of Sciences USA, 107(17), 7722-7727.

Marco, I. (2013). Integrated soybean protection against diseases. Agrobusiness Today, 11(258), 16-21 (in Ukrainian).

Matamoros, M. A., Dalton, D. A., Ramos, J., Clemente, M. R., Rubio, M. C., \& Becana, M. (2003). Biochemistry and molecular biology of antioxidants in the rhizobia - legume symbiosis. Plant Physiology, 133(2), 499-509.

Mittler, R. (2002). Oxidative stress, antioxidants and stress tolerance. Trends Plant Sciences, 7, 405-410.

Mohammadi, K., Sohrabi, Y., Heidari, G., Khalesro, S., \& Majidi, M. (2012). Effective factors on biological fiation. Agricaltural Research, 7(12), 1782-1788.

Moran, J. F., James, E. K., Rubio, M. C., Sarath, G., Klucas, R. V., \& Becana, M. (2003). Functional characterization and expression of a cytosolic iron-superoxide dismutase from cowpea root nodules. Plant Physiology, 133(2), 773-782.

Moreira, R. A., Ainouz, I. L., Oliveira, J. T., \& Cavada, B. S. (1991). Plant lectins, chemical and biological aspects. Memorias Instituto Oswaldo Cruz, 86(2).

Nakano, Y., \& Asada, K. (1981). Hydrogen peroxidase is scavenged by ascorbate-specific peroxidase in spinach chloroplasts. Plant Cell Physiology, 22(5), 867-880.

Nikolaevsky, V., Sirenko, V., \& Titova, L. (2017). Effect of pre-seed bacterialization of seeds on disease development and yield of soybean. Stiinta Agricola, $1,55-59$.

Owens, R. A., Blecburn, M., \& Ding, B. (2001). Possible involvement of the phloem lectin in long-distance varied movement. Molecular Plant Microbe Interact, 14(7), 905-909.

Parsiavash, L., Saboora, A., \& Nejad, S. Z. M. (2015). Investigating on the stability of peroxidase extracted from soybean (Glycine max var. williams) and effects of $\mathrm{Na}^{+}$and $\mathrm{K}^{+}$ions on its activity. Journal of Cell and Molecular Research, $7(2), 94-101$.

Petrichenko, V. F., \& Kots, S. Y. (2014). Symbiotic systems in modern agricultural production. Bulletin of NAS of Ukraine, 3, 57-66 (in Ukrainian).

Raychauhuri, S. S., \& Deng, X. W. (2000). The role of superxide dismutase in combating oxidative stress in higher plants. The Botanical Review, 66(1), 89-98.

Rubio, M. C., James, E. K., Clemente, M. R., Bucciarelli, B., Fedorova, M., Vance, C. P., \& Becana, M. (2004). Localization of superoxide dismutases and hydrogen peroxide in legume root nodules. The American Phytopathological Society, 17(12), 1294-1305.

Schmitz, N., Huystee, R., \& Gijzen, M. (1997). Characterization of anionic soybean (Glycine max) seed coat peroxidase. Canadian Journal of Botany, 75(8), 1336-1341.

Sergienko, V. (2012). Diseases of soybeans and measures of its limitation. Agrobusiness Today, 11(234), 28-30 (in Ukrainian).

Shao, H.-B., Chu, L.-Y., Lu, Z.-H., \& Kang, C.-M. (2008). Primary antioxidant free radical scavenging and redox signaling pathways in higher plant cells. International Journal of Biological Sciences, 4(1), 8-14.

Sharma, P., Jha, A. B., Dubey, R. S., \& Pessarakli, M. (2012). Reactive oxygen species, oxidative damage, and antioxidative defense mechanism in plants under stressful conditions. Journal of Botany, 20(12), 1-26.

Zhiznevskaya, G. Y., Troitskaya, G. N., Borodenko, L. I., \& Izmailov, S. F. (2001). Peroxidase and catalase in root nodules of fodder beans at an effective and ineffective symbiosis with rhizobia. Physiology and Biochemistry of Cultural Plants, 33(4), 285-290 (in Ukrainian). 